Check for updates

Cite this: RSC Adv., 2019, 9, 36931

Received 19th October 2019

Accepted 4th November 2019

DOI: 10.1039/c9ra08566a

rsc.li/rsc-advances

\section{Unusual constituents from the medicinal mushroom Ganoderma lingzhi†}

\author{
Zhen-Zhu Zhao, ${ }^{\text {ab }}$ Xu-Bo Liang, ${ }^{a}$ Wei-Sheng Feng, (D) ab Ya Wu, ${ }^{\text {ab }}$ Yan-Le Zhi, ${ }^{\text {ab }}$ \\ Gui-Min Xue, ${ }^{\text {ab }}$ He-Ping Chen (iD *c and Ji-Kai Liu ${ }^{* c}$
}

Extensive studies have revealed that triterpenoids, meroterpenoids, and polysaccharides are the main constituents of the well-known traditional Chinese medicinal mushroom Ganoderma. In this study, we report seven previously undescribed sesquiterpenoids, including six gymnomitranes (1-6) and a novel type of sesquiterpenoid (8), together with a polyketide (7) and a known steroid (9) from the fruiting bodies of Ganoderma lingzhi, a fungus used as traditional medicine and food supplement in East Asia for ages. The structures of 1-8 were deduced by analysis of spectroscopic data, X-ray single crystal diffractions and TDDFT/ECD calculations. Compound 8 possessed an unusual 14(7 $\rightarrow 6)$-cuparane scaffold. Compound 9 exhibited weak cytotoxicity against the five human cancer cell lines HL-60, MCF7. SW480, A549, and SMMC-7721 with $I_{50}$ values of 18.0-32.3 $\mu \mathrm{M}$. A simple structure-activityrelationship (SAR) investigation by acetylating the $5-\mathrm{OH}$ of 9 (9a) suggested that the $5-\mathrm{OH}$ is essential for its cytotoxicity. Additionally, the biosynthetic pathways for compounds 2 and 8 are discussed.

\section{Introduction}

Ganoderma have been used as traditional and folk medicines for thousands of years in East Asia. Ganoderma natural products have long been a hot topic for their health-preserving and therapeutic effects. ${ }^{\mathbf{1}, 2}$ The Ganoderma lucidum complex includes more than 23 described species. ${ }^{3}$ This genus has proved to be a prolific source of triterpenes, and to date, more than 400 examples have been reported. ${ }^{4}$ Ganoderma constituents have shown anti-tumour, anti-inflammatory, anti-microbial, acetylcholinesterase inhibitory, ${ }^{5}$ and pancreatic lipase inhibitory, ${ }^{6}$ and have emerging potency as anti-aging agents. ${ }^{7}$ Extensive studies have revealed that the polysaccharides and triterpenes are responsible for the anti-tumour and immunomodulatory functions. ${ }^{5}$ Notably, Ganoderma meroterpenoids have widely attracted attention in the past six years due to their intriguing structures and diverse biological activities. ${ }^{8}$ All these efforts have illuminated and enriched the chemical profile of Ganoderma secondary metabolites, which has made it possible for

${ }^{a}$ College of Pharmacy, Henan University of Chinese Medicine, Zhengzhou 450046, China

${ }^{b}$ Collaborative Innovation Center for Respiratory Disease Diagnosis and Treatment and Chinese Medicine Development of Henan Province, Zhengzhou 450046, China

'School of Pharmaceutical Sciences, South-Central University for Nationalities, Wuhan 430074, China.E-mail: chenhp@mail.scuec.edu.cn; liujikai@mail.scuec.edu.cn

$\dagger$ Electronic supplementary information (ESI) available: The 1D \& 2D NMR, MS, and crystallographic data of compounds 1-9. CCDC 1561836 and 1851594. For ESI and crystallographic data in CIF or other electronic format see DOI: 10.1039/c9ra08566a
Ganoderma to be developed as a regular drug rather than as a dietary supplement. ${ }^{\mathbf{9}, 10}$

Sesquiterpenoids are the most abundant type of secondary metabolites in mushrooms. ${ }^{\mathbf{1 1}}$ However, in contrast to the attention that has been paid on the triterpenes, research on sesquiterpenes from Ganoderma fruiting bodies is still unfolding. The Ganoderma genome-sequencing, as part of the herb genomics plan, revealed that Ganoderma encodes terpene synthases for monoterpene, sesquiterpene, and diterpene backbones. ${ }^{12}$ However, hitherto only fourteen sesquiterpenoids have been reported from the fermentation products of three different Ganoderma species, ${ }^{4}$ while only two other sesquiterpenes were isolated from Ganoderma fruiting bodies, i.e. ganosinensine ${ }^{\mathbf{1 3}}$ and gymnomitrane-3 $\alpha, 5 \alpha, 9 \beta, 15$-tetrol. ${ }^{14}$ Besides, the first sesquiterpene ganosinensine was then regarded as a metabolite of the symbiotic bacteria of $G$. sinense.

Ganoderma lingzhi, widely distributed in China, Japan, and Korea, is a new species firstly proposed by Y.-C. Dai in $2012^{15}$ and then regarded as a later synonym of $G$. sichuanense, although there is still a controversy about the taxonomy between G. lingzhi and G. sichuanense ${ }^{\mathbf{1 6 , 1 7}}$ Comparing with the other Ganoderma species, the secondary metabolites of $G$. lingzhi have rarely been investigated. Y. M. Yan et al. reported six meroterpenoids with neural stem cells proliferation-promoting activity from this fungus. ${ }^{18}$

In order to explore diverse constituents for the identification of bioactive natural products from Ganoderma, a detailed chemical investigation on $G$. lingzhi led to the isolation of six rarely-encountered gymnomitrane-type sesquiterpenoids (1-6), an unusual type sesquiterpene (8), a polyketide (7) and an 
unusual ergosterol (9) from the low-polarity fractions of the crude extract (Fig. 1). Herein we report the isolation, structural characterization, biological activity, and feasible biosynthetic pathways of the compounds 1-9.

\section{Results and discussion}

Compound 1, colourless needles $(\mathrm{MeOH})$, had a molecular formula of $\mathrm{C}_{15} \mathrm{H}_{22} \mathrm{O}_{2}$ deduced by HREIMS analysis. The 1D NMR data (Tables 1 and 2) displayed signals for three methyl singlets, four $\mathrm{sp}^{3}$ methylenes, a trisubstituted double bond, two $\mathrm{sp}^{3}$ methines (one oxygenated carbon $\delta_{\mathrm{C}} 77.6$ ), an aldehyde group $\left(\delta_{\mathrm{C}}\right.$ 193.0), and three $\mathrm{sp}^{3}$ quaternary carbons. The data of 1 showed similarity to those of (+)-5-hydroxybarbatenal, ${ }^{19}$ a gymnomitrane-type sesquiterpene isolated from the root of Beilschmiedia tsangii. The data also suggested a hydroxy substituted at $\mathrm{C}-10$ in 1 rather than C-5 in (+)-5-hydroxybarbatenal. This change was supported by the mutual ${ }^{1} \mathrm{H}-{ }^{1} \mathrm{H}$ COSY correlations between $\mathrm{H}-9\left(\delta_{\mathrm{H}} 1.76,1.61\right)$ and $\mathrm{H}-10\left(\delta_{\mathrm{H}}\right.$ $3.67)$, along with the HMBC correlations from Me-12 $\left(\delta_{\mathrm{H}} 1.06\right)$ to C-10 $\left(\delta_{\mathrm{C}}\right.$ 77.6) (Fig. 2). The relative configuration of 1 was determined to be $2 S^{*}, 6 R^{*}, 7 R^{*}, 10 R^{*}, 11 S^{*}$ in accordance with the diagnostic ROESY correlations of $\mathrm{H}-1 \beta / \mathrm{H}_{3}-13 / \mathrm{H}_{3}-14$, and $\mathrm{H}_{3}-12$ / $\mathrm{H}-2 / \mathrm{H}-10$ (Fig. 3). The absolute configuration of $\mathbf{1}$ was unequivocally established as $2 S, 6 R, 7 R, 10 R, 11 S$ by single crystal $\mathrm{X}$-ray diffraction analysis (Fig. 4) with the Flack parameter $=$ $0.09(6)$. Hence, the structure of 1 was established as shown in Fig. 1, and named as $10 \alpha$-hydroxy-gymnomitr-3-en-15-al.

Compound 2 was obtained as colourless crystals ( $\mathrm{MeOH})$. Its molecular formula was determined to be $\mathrm{C}_{15} \mathrm{H}_{22} \mathrm{O}_{2}$ by HREIMS analysis with the ion peak at $m / z 234.1617$ (calcd for $\mathrm{C}_{15} \mathrm{H}_{22} \mathrm{O}_{2}$ 234.1620), indicating the presence of five degrees of unsaturation. The planar structure of $\mathbf{2}$ was elucidated by interpretation of its NMR spectra. The 1D NMR spectra of 2 presented three

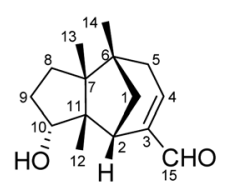

1
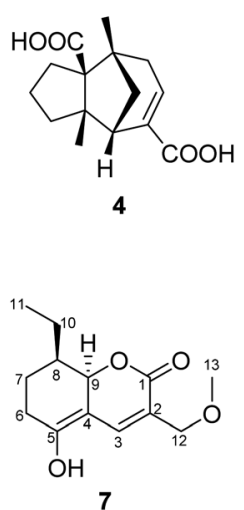
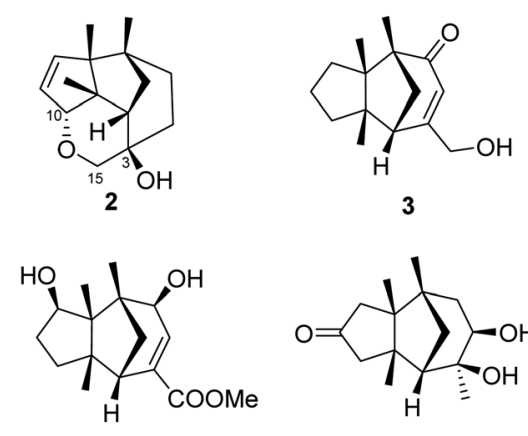

5

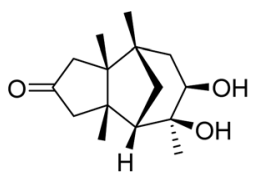

6
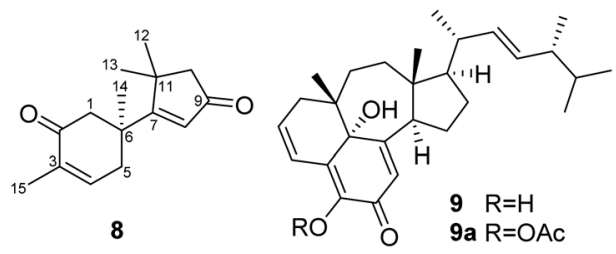

Fig. 1 Structures of compounds 1-9, and 9a. methyls $\left(\delta_{\mathrm{H}} / \delta_{\mathrm{C}}: 0.94 / 20.0,0.97 / 24.7,1.11 / 27.4\right)$, four methylenes $\left(\delta_{\mathrm{C}} 31.5,32.7,38.0,74.2\right)$, two sp ${ }^{3}$ methines $\left(\delta_{\mathrm{C}} 53.9,88.8\right)$, two olefinic carbons $\left(\delta_{\mathrm{C}} 130.2,142.3\right)$, and four $\mathrm{sp}^{3}$ quaternary carbons $\left(\delta_{\mathrm{C}} 43.6,52.4,64.5,69.7\right)$ (Tables 1 and 2). The aforementioned data indicated that 2 is a sesquiterpene derivative harbouring a gymnomitrane skeleton analogous to that of $\mathbf{1}$. In addition to the tricyclic system and one double bond, the remaining one degree of unsaturation revealed the existence of an additional ring. Analysis of the 2D NMR spectra of 2 helped to establish its structure unambiguously. The HMBC correlations from $\mathrm{H}_{3}-13\left(\delta_{\mathrm{H}} 0.97\right)$ to $\mathrm{C}-8\left(\delta_{\mathrm{C}} 142.3\right)$ revealed that the double bond was located between C-8 and C-9. Additionally, the $\mathrm{HMBC}$ correlations from $\mathrm{H}-4\left(\delta_{\mathrm{H}} 1.86,1.48\right)$ to C-3 $\left(\delta_{\mathrm{C}} 69.7\right)$ and $\mathrm{C}-15\left(\delta_{\mathrm{C}} 74.2\right)$, and from $\mathrm{H}-15\left(\delta_{\mathrm{H}} 3.43,3.27\right)$ to C-10 $\left(\delta_{\mathrm{C}} 88.8\right)$ suggested an ether linkage between $\mathrm{C}-10$ and $\mathrm{C}-15$, and a hydroxy group substituted at C-3 (Fig. 2). The key ROESY correlations between $\mathrm{H}_{3}-12\left(\delta_{\mathrm{H}} 1.11\right) / \mathrm{H}-10\left(\delta_{\mathrm{H}} 4.11\right)$, together with biosynthetic comparison with the structure of $\mathbf{1}$ and the structure inflexibility of 2 , the absolute configuration of 2 was assigned to be $2 S, 3 R, 6 R, 7 R, 10 R, 11 S$. The above assignment indicated the structure of 2 as a unique boat-like molecule bearing a rigid structure unprecedented in the gymnomitrane family, it was given the name $10 \alpha, 15$-epoxy-gymnomitr-8-en-3 $\beta$ ol.

Compound 3 was isolated as a white amorphous powder. The molecular formula was deduced from the sodium adduct ion peak at $m / z 257.1514$ (calcd for $\mathrm{C}_{15} \mathrm{H}_{22} \mathrm{O}_{2} \mathrm{Na}, 257.1512$ ) as $\mathrm{C}_{15} \mathrm{H}_{22} \mathrm{O}_{2}$ in the HRESIMS analysis. The ${ }^{13} \mathrm{C}$ NMR spectrum (Table 2) showed signals for 15 carbons, including three methyls, five methylenes (one was oxygenated $\delta_{\mathrm{C}} 65.6$ ), one $\mathrm{sp}^{3}$ methines, three $\mathrm{sp}^{3}$ quaternary carbons, and an $\alpha, \beta$-unsaturated ketone group $\left(\delta_{\mathrm{C}} 169.5,122.3,205.5\right)$. The data shared striking similarity with those of the known compound ganosinensine isolated from $G$. sinense, ${ }^{13}$ indicating that 3 was also a gymnomitrane-type sesquiterpene. The structural difference between ganosinensine and 3 was that the C-9 in 3 remained unoxygenated, supported by the ${ }^{1} \mathrm{H}-{ }^{1} \mathrm{H}$ COSY correlations of $\mathrm{H}-$ $8\left(\delta_{\mathrm{H}} 1.46,1.17\right) / \mathrm{H}-9\left(\delta_{\mathrm{H}} 1.53,1.43\right) / \mathrm{H}-10\left(\delta_{\mathrm{H}} 1.59,1.36\right)($ Fig. 2$)$ and HRESIMS data. The configuration of 3 was identical with that of 1 by analysis of the ROESY spectrum (Fig. 3). Thus, compound 3 was determined as shown in Fig. 1, and named as 15-hydroxy-gymnomitr-3-en-5-one.

The HRESIMS analysis of $\mathbf{4}$ suggested the molecular formula was $\mathrm{C}_{15} \mathrm{H}_{20} \mathrm{O}_{4}\left(\mathrm{~m} / \mathrm{z} 263.1291[\mathrm{M}-\mathrm{H}]^{-}\right.$, calcd for $\mathrm{C}_{15} \mathrm{H}_{19} \mathrm{O}_{4}$, 263.1289), appropriate for six degrees of unsaturation. The ${ }^{1} \mathrm{H}$ and ${ }^{13} \mathrm{C}$ NMR data (Tables 1 and 2) showed representative chemical shifts for a gymnomitrane skeleton: two methyl singlets $\left(\delta_{\mathrm{H}} 1.13,1.21 ; \delta_{\mathrm{C}} 24.7,30.6\right)$, three $\mathrm{sp}^{3}$ quaternary carbons $\left(\delta_{\mathrm{C}} 47.0,61.6,71.6\right)$, two carbonyl groups $\left(\delta_{\mathrm{C}} 170.7\right.$, $178.7)$, one tri-substituted double bond $\left(\delta_{\mathrm{C}} 140.3,137.7 ; \delta_{\mathrm{H}}\right.$ 6.80). The HMBC correlations from $\mathrm{H}-2\left(\delta_{\mathrm{H}} 2.61\right)$ to $\mathrm{C}-3\left(\delta_{\mathrm{C}}\right.$ $137.7)$ and $\mathrm{C}-4\left(\delta_{\mathrm{C}} 140.3\right)$ allowed the assignment of C-3/C-4 as a double bond (Fig. 2). The gymnomitrane scaffold and the double bond accounted for four out of six degrees of unsaturation. The remaining two degrees of unsaturation were assigned to two carboxylic groups at C-13 and C-15, which was supported by the HMBC correlations from $\mathrm{H}-8\left(\delta_{\mathrm{H}} 2.22\right)$ to C-13 
Table $1{ }^{1} \mathrm{H}$ NMR data of compounds $1-8(600 \mathrm{MHz})$

\begin{tabular}{|c|c|c|c|c|c|c|}
\hline No. & $\mathbf{1}^{b}$ & $2^{a}$ & $3^{b}$ & $4^{a}$ & $5^{a}$ & $6^{b}$ \\
\hline 1 & $\begin{array}{l}2.05, \text { dd }(11.8,3.5), \\
1.37, \text { d }(11.8)\end{array}$ & $\begin{array}{l}1.77 \text {, dd }(10.0,2.5) \\
1.80, \text { dd }(10.0,2.5)\end{array}$ & $\begin{array}{l}2.01, \text { dd }(11.5,4.5), \\
1.87, \text { d }(11.5)\end{array}$ & $\begin{array}{l}2.79, \text { dd }(11.0,5.0) \\
1.42 \text {, d (11.0) }\end{array}$ & $\begin{array}{l}1.67, \text { dd }(11.8,4.5), \\
1.60, \mathrm{~d}(11.8)\end{array}$ & $\begin{array}{l}\text { 1.59, ddd (12.0, 5.0, } \\
2.8), 2.11 \text {, d (12.0) }\end{array}$ \\
\hline 2 & $2.59, \mathrm{~d}(3.5)$ & $1.61, \mathrm{t}(2.5)$ & $2.11, \mathrm{~d}(4.5)$ & $2.61, \mathrm{~d}(5.0)$ & $2.51, \mathrm{~d}(4.5)$ & $1.85, \mathrm{~d}(5.0)$ \\
\hline 4 & $6.73, \mathrm{t}$-like (2.5) & $\begin{array}{l}\text { 1.86, overlapped, } 1.48 \\
\text { ddd }(16.8,7.6,5.2)\end{array}$ & 6.04, br. s & 6.80, dd $(4.0,3.0)$ & $6.88, \mathrm{~d}(4.0)$ & 3.31, dd $(11.2,6.3)$ \\
\hline 5 & $\begin{array}{l}2.55, \text { dd }(22.0,2.5) \\
2.24, \text { dd }(22.0,2.5)\end{array}$ & $\begin{array}{l}\text { 1.84, overlapped, } 1.32 \\
\text { ddd }(16.8,13.3,8.0)\end{array}$ & & $\begin{array}{l}2.49, \text { dd }(21.0,4.0) \\
2.16, \text { dd }(21.0,3.0)\end{array}$ & $3.95, \mathrm{~d}(4.0)$ & $\begin{array}{l}1.82 \text {, dd }(14.0,6.3), \\
1.46 \text {, dd }(14.0,11.2)\end{array}$ \\
\hline 8 & $1.50, \mathrm{~m}, 1.23, \mathrm{~m}$ & $5.65, \mathrm{~d}(5.8)$ & $\begin{array}{l}\text { 1.46, m, 1.17, } \\
\text { overlapped }\end{array}$ & $\begin{array}{l}2.22, \text { ddd }(14.0,9.5 \\
8.0), 1.64, \text { ddd }(14.0 \\
6.0,4.0)\end{array}$ & 3.74, overlapped & $\begin{array}{l}\text { 2.61, d (19.7), 1.89, } \\
\text { d (19.7) }\end{array}$ \\
\hline 9 & $1.76, \mathrm{~m}, 1.61, \mathrm{~m}$ & 5.60, dd $(5.8,2.1)$ & $1.53, \mathrm{~m}, 1.43, \mathrm{~m}$ & $1.60, \mathrm{~m}, 1.54, \mathrm{~m}$ & $1.74, \mathrm{~m}$ & \\
\hline 10 & 3.67, t-like (5.0) & $4.11, \mathrm{~d}(2.1)$ & $\begin{array}{l}\text { 1.59, overlapped, } 1.36 \text {, } \\
\text { m }\end{array}$ & $\begin{array}{l}\text { 1.69, ddd }(14.0,7.0, \\
4.0), 1.25, \mathrm{~m}\end{array}$ & $\begin{array}{l}\text { 1.27, m, 1.14, } \\
\text { overlapped }\end{array}$ & $\begin{array}{l}3.00, \mathrm{~d}(19.8), 2.13 \\
\mathrm{~d}(19.8)\end{array}$ \\
\hline 12 & 1.06. S & $1.11, \mathrm{~s}$ & 1.17, s & $1.21, \mathrm{~s}$ & $1.12, \mathrm{~s}$ & $1.22, \mathrm{~s}$ \\
\hline 13 & $0.94, \mathrm{~s}$ & $0.97, \mathrm{~s}$ & $0.98, \mathrm{~s}$ & & $1.05, \mathrm{~s}$ & $1.01, \mathrm{~s}$ \\
\hline 14 & $0.99, \mathrm{~s}$ & $0.94, \mathrm{~s}$ & $1.07, \mathrm{~s}$ & $1.13, \mathrm{~s}$ & $0.93, \mathrm{~s}$ & $0.90, \mathrm{~s}$ \\
\hline 15 & $9.45, \mathrm{~s}$ & $\begin{array}{l}3.43, \mathrm{~d}(10.0), 3.27 \\
\mathrm{~d}(10.0)\end{array}$ & $\begin{array}{l}4.35, \text { br. dd }(17.0,6.0) \\
4.25, \text { br. dd }(17.0,6.0)\end{array}$ & & & $1.38, \mathrm{~s}$ \\
\hline MeO- & & & & & $3.74, \mathrm{~s}$ & \\
\hline
\end{tabular}

$\left(\delta_{\mathrm{C}} 178.7\right)$, and from $\mathrm{H}-2\left(\delta_{\mathrm{H}} 2.61\right)$ and $\mathrm{H}-4\left(\delta_{\mathrm{H}} 6.80\right)$ to $\mathrm{C}-15\left(\delta_{\mathrm{C}}\right.$ 170.7) (Fig. 2). The relative stereochemistry of 4 is identical to that of $\mathbf{1}$ by analysis of the ROESY spectrum (Fig. 3). Hence, 4 was named gymnomitr-3-ene-13,15-dioic acid.

The 1D NMR data of 5 (Tables 1 and 2) exhibited four methyl singlets (one methoxy group), three $\mathrm{sp}^{3}$ methylenes, three $\mathrm{sp}^{3}$ methines (two oxygenated), one tri-substituted double bond, three $\mathrm{sp}^{3}$ quaternary carbons, and one carbonyl group. The data displayed similarity to those of $\mathbf{1 - 4}$, suggesting the gymnomitrane skeleton of 5. Compared to compound 1, two hydroxy groups substituted at C-5 and C-8 in 5, rather than a hydroxy group at $\mathrm{C}-10$ in 1 . The changes were supported by the HMBC correlations from $\mathrm{H}_{3}-13\left(\delta_{\mathrm{H}} 1.05\right)$ to C-8 $\left(\delta_{\mathrm{C}} 76.2\right), \mathrm{H}_{3}-14\left(\delta_{\mathrm{H}} 0.93\right)$ to $\mathrm{C}-5\left(\delta_{\mathrm{C}} 71.6\right)$, and $\mathrm{H}_{3}-12\left(\delta_{\mathrm{H}} 1.12\right)$ to the methylene $\mathrm{C}-10\left(\delta_{\mathrm{C}}\right.$
33.6) (Fig. 2). Furthermore, the HMBC correlation from the methoxy singlet at $\delta_{\mathrm{H}} 3.74$ to the carbonyl group $\delta_{\mathrm{C}} 169.1 \mathrm{sug}$ gested the presence of a methyl ester group at C-15 in compound 5 (Fig. 2). The above assignments are consistent with the molecular formula $\mathrm{C}_{16} \mathrm{H}_{24} \mathrm{O}_{4}$, which was determined by HRESIMS data. The relative configurations of C-5 and C- 8 were assigned as $S^{*}$ and $R^{*}$, respectively, by the key ROESY correlations between $\mathrm{H}-5\left(\delta_{\mathrm{H}} 3.95\right)$ and $\mathrm{H}-8\left(\delta_{\mathrm{H}} 3.74\right)$ (Fig. 3). The absolute configuration of $\mathbf{5}$ was unequivocally settled by single crystal X-ray diffraction analysis as $2 S, 5 S, 6 R, 7 S, 8 R, 11 S$ (Fig. 5). Thus, compound 5 was identified as methyl $5 \beta, 8 \beta$-dihydroxygymnomitr-3-en-15-oate.

Compounds 6 and 7 were isolated as an inseparable mixture. The NMR spectra of the mixture presented complicated but

Table $2{ }^{13} \mathrm{C}$ NMR Data of Compounds 1-8 (150 MHz)

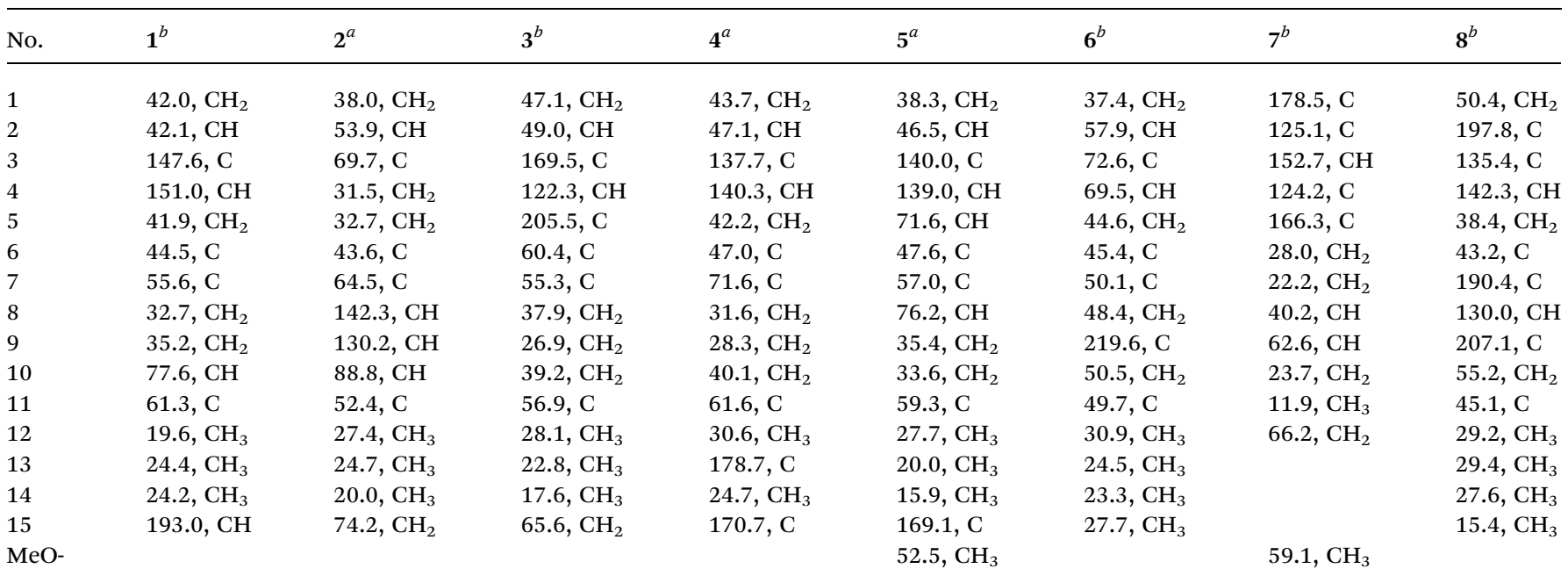

${ }^{a}$ Measured in $\mathrm{CD}_{3} \mathrm{OD} .{ }^{b}$ Measured in $\mathrm{CDCl}_{3}$. 

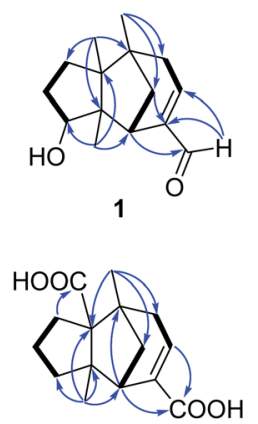

4

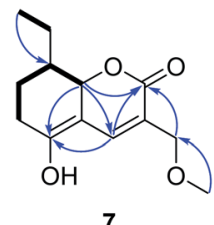

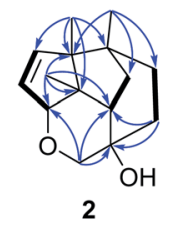

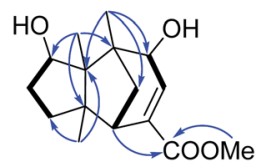

5

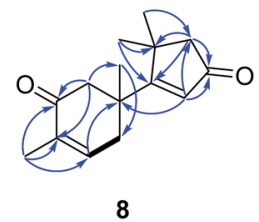

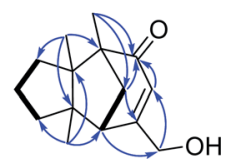

3

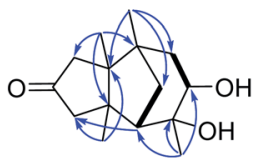

6

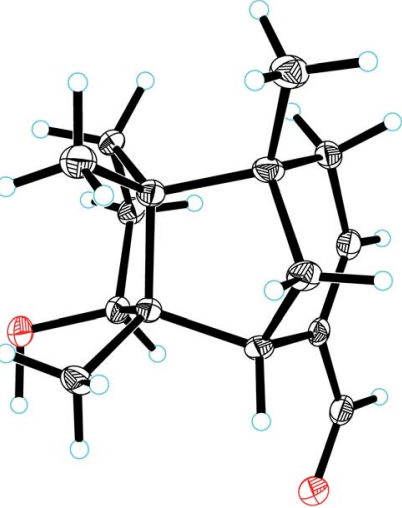

Fig. 4 ORTEP drawing of compound 1. trane skeleton substituted by two hydroxy groups at C-3 $\left(\delta_{\mathrm{C}}\right.$ 72.6), C-4 ( $\left.\delta_{\mathrm{C}} 69.5\right)$, and a carbonyl group at C-9 $\left(\delta_{\mathrm{C}} 219.6 \mathrm{C}\right)$, which were supported by the HMBC correlations from $\mathrm{H}_{3}-15\left(\delta_{\mathrm{H}}\right.$ $1.38)$ to $\mathrm{C}-3$ and $\mathrm{C}-4$, and from $\mathrm{H}-8\left(\delta_{\mathrm{H}} 2.61,1.89\right), \mathrm{H}-10\left(\delta_{\mathrm{H}} 3.00\right.$, 2.13) to C-9 $\left(\delta_{\mathrm{C}} 219.6\right)$ (Fig. 2). The assignments were in accordance with the molecular formula of $\mathrm{C}_{15} \mathrm{H}_{24} \mathrm{O}_{3}$ generated by

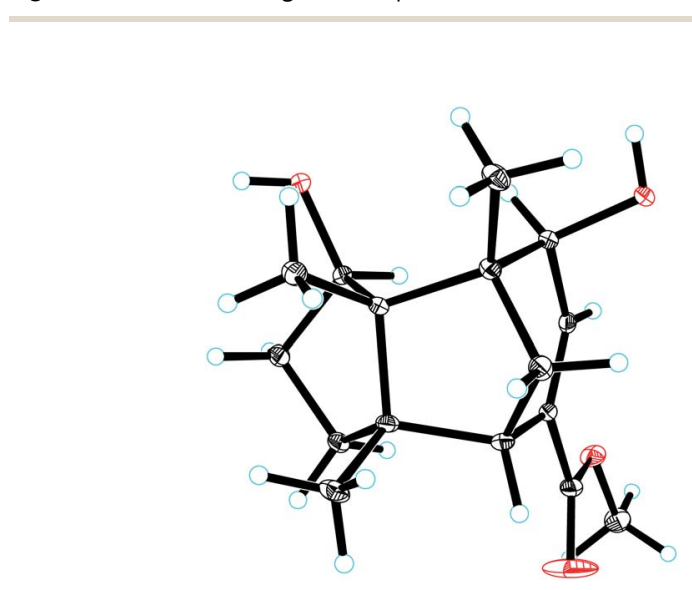

Fig. 5 ORTEP drawing of compound 5.

HREIMS ion peak at $m / z 252.1724[\mathrm{M}]^{+}$(calcd for 252.1725). As for the relative configuration of $\mathbf{6}$, both of the hydroxy groups at C- 3 and C- 4 were assigned to be $\beta$ orientated by the diagnostic

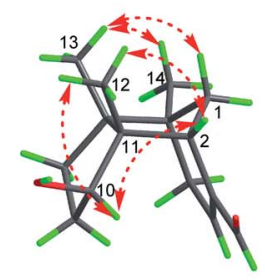

1

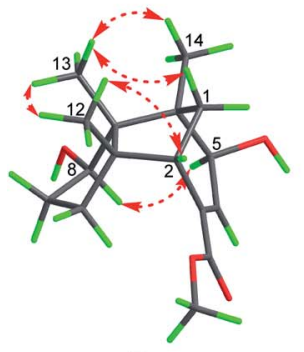

5
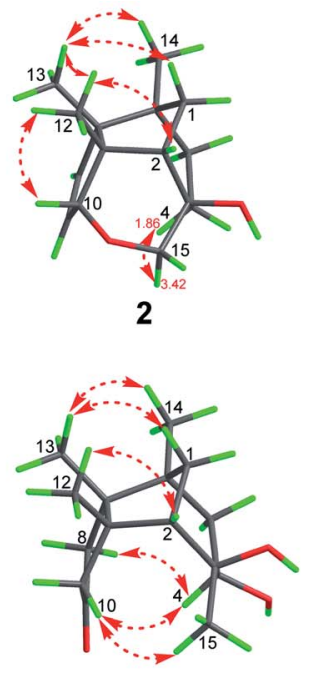

6
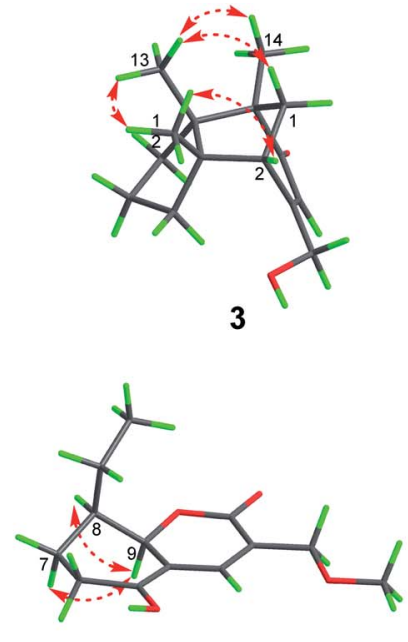

7
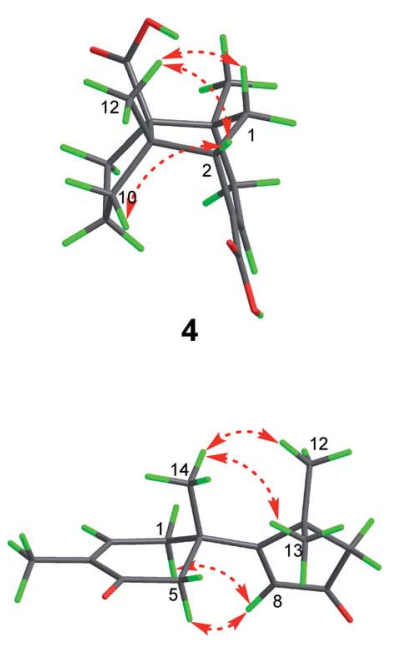

8

Fig. 3 Selected ROESY correlations of 1-8. 
ROESY correlations between $\mathrm{H}-8 \alpha\left(\delta_{\mathrm{H}} 2.61\right)$ and $\mathrm{H}-4\left(\delta_{\mathrm{H}} 3.31\right), \mathrm{H}-$ $10 \alpha\left(\delta_{\mathrm{H}} 2.98\right)$ and $\mathrm{H}-4$, and between $\mathrm{H}_{3}-15\left(\delta_{\mathrm{H}} 1.38\right)$ and $\mathrm{H}-10 \alpha$ (Fig. 4). Thus, compound 6 was established to be $3 \beta, 4 \beta$-dihydroxy-gymnomitr-9-one.

The other group of signals included a methyl triplet $\left(\delta_{\mathrm{H}} 1.01\right.$; $\left.\delta_{\mathrm{C}} 11.9\right)$, a methoxy group $\left(\delta_{\mathrm{H}} 3.44 ; \delta_{\mathrm{C}} 59.1\right)$, four methylenes (one oxygenated), three methines (one oxygenated, one olefinic), and four $\mathrm{sp}^{2}$ quaternary carbons (Tables 2 and 3). The data displayed characteristic signals similar to those of xylaolide A. ${ }^{20}$ Analysis of the 2D NMR spectra of 7 revealed that C-12 was substituted by a methoxy group in 7 instead of a hydroxy group in xylaolide $\mathrm{A}$, which was supported by the $\mathrm{HMBC}$ correlation from the methoxy proton $\left(\delta_{\mathrm{H}} 3.44\right)$ to $\mathrm{C}-12\left(\delta_{\mathrm{C}} 66.2\right)$ (Fig. 2). Other parts of the structure, along with the relative configuration, were consistent to those of xylaolide $\mathrm{A}$ by analysis of the ROESY spectrum (Fig. 3). The above assignments accounted for a molecular formula of $\mathrm{C}_{13} \mathrm{H}_{18} \mathrm{O}_{4}$, in accord with the HRESIMS result $\left(\mathrm{m} / \mathrm{z} 261.1098[\mathrm{M}+\mathrm{Na}]^{+}\right.$, calcd for $\left.\mathrm{C}_{13} \mathrm{H}_{18} \mathrm{O}_{4} \mathrm{Na}, 261.1098\right)$. Therefore, compound 7 was named as 12-O-methyl-xylaolide A.

Compound 8, a colourless oil, had the molecular formula $\mathrm{C}_{15} \mathrm{H}_{20} \mathrm{O}_{2}$ determined by HREIMS analysis at $m / z 232.1460[\mathrm{M}]^{+}$ (calcd $\mathrm{C}_{15} \mathrm{H}_{20} \mathrm{O}_{2}, 232.1463$ ), requiring six degrees of unsaturation. The 1D NMR data presented signals for four methyl singlets $\left(\delta_{\mathrm{H}} 1.37,1.38,1.40,1.78 ; \delta_{\mathrm{C}} 27.6,29.2,29.4,15.4\right)$, three methylenes, two $\mathrm{sp}^{3}$ quaternary carbons, and two pairs of $\alpha, \beta$ unsaturated ketone groups $\left(\delta_{\mathrm{H}} 6.64, \delta_{\mathrm{C}} 142.3,135.4,197.8 ; \delta_{\mathrm{H}}\right.$ $5.93, \delta_{\mathrm{C}} 130.0,190.4,207.1$ ) (Tables 2 and 3 ). The $1 \mathrm{D}$ NMR data accounted for four degrees of unsaturation, implying the existence of two rings in $\mathbf{8}$. The planar structure of $\mathbf{8}$ was established by analysis of the 2D NMR data. The key HMBC correlations from $\mathrm{H}_{3}-14\left(\delta_{\mathrm{H}} 1.37\right)$ to $\mathrm{C}-1\left(\delta_{\mathrm{C}} 50.4\right)$, C-5 $\left(\delta_{\mathrm{C}} 38.4\right)$, and C-6 $\left(\delta_{\mathrm{C}}\right.$ 43.2), and from $\mathrm{H}-1\left(\delta_{\mathrm{H}} 2.87,2.59\right)$ to $\mathrm{C}-2\left(\delta_{\mathrm{C}} 197.8\right)$, and from $\mathrm{H}_{3}-15\left(\delta_{\mathrm{H}} 1.78\right)$ to $\mathrm{C}-2, \mathrm{C}-3\left(\delta_{\mathrm{C}} 135.4\right)$, and $\mathrm{C}-4\left(\delta_{\mathrm{C}} 142.3\right)$, along with the ${ }^{1} \mathrm{H}-{ }^{1} \mathrm{H}$ COSY correlation between $\mathrm{H}-4\left(\delta_{\mathrm{H}} 6.64\right)$ and $\mathrm{H}-5$ $\left(\delta_{\mathrm{H}} 2.83,2.50\right)$ (Fig. 2), allowed the completion of a six-

Table $3{ }^{1} \mathrm{H}$ NMR Data of Compounds 7 and 8 (600 MHz, CD $3 \mathrm{OD}$ )

\begin{tabular}{lll}
\hline No. & 7 & 8 \\
\hline 1 & & $2.87, \mathrm{~d}(15.8), 2.59, \mathrm{~d}(15.8)$ \\
3 & $7.77, \mathrm{~s}$ & \\
4 & & $6.64, \mathrm{br} . \mathrm{dd}(6.0,3.0)$ \\
5 & & $2.83, \mathrm{dd}(17.6,2.4)$, \\
& & \\
6 & 2.59, overlapped & \\
7 & $1.79, \mathrm{~m}, 1.71$, overlapped & $5.93, \mathrm{~s}$ \\
8 & $1.44, \mathrm{~m}$ & \\
9 & $4.87, \mathrm{~d}(3.2)$ & $2.36, \mathrm{~s}(2 \mathrm{H})$ \\
10 & 1.70, overlapped, \\
& 1.42, overlapped & \\
11 & $1.01, \mathrm{t}(7.0)$ & $1.38 \mathrm{~s}$ \\
12 & $4.32, \mathrm{~d}(12.4), 4.29, \mathrm{~d}(12.4)$ & $1.40, \mathrm{~s}$ \\
13 & & $1.37, \mathrm{~s}$ \\
14 & & $1.78, \mathrm{~s}$ \\
15 & & \\
MeO- & $3.44, \mathrm{~s}$
\end{tabular}

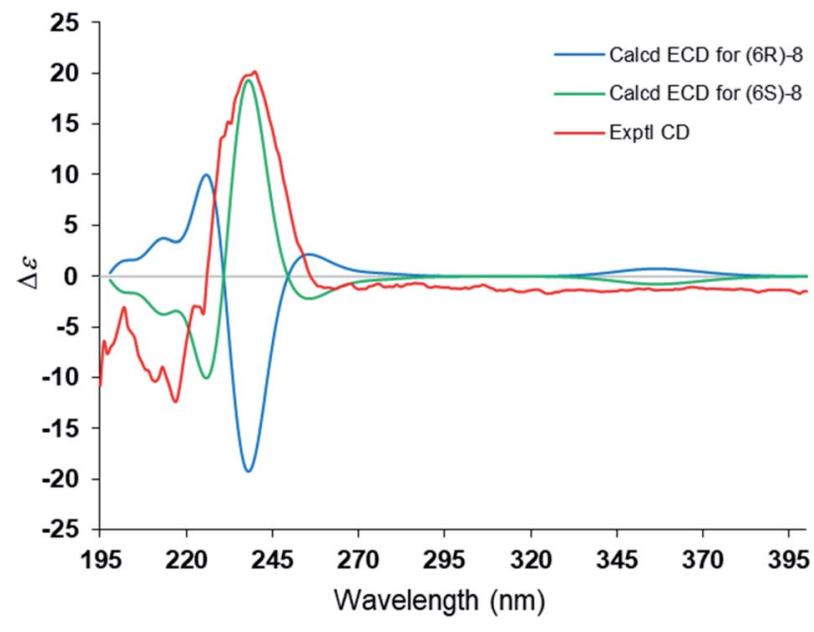

Fig. 6 Comparison of the experimental $C D$ and calculated ECD spectra of compound 8 .

membered ring. Moreover, the characteristic HMBC correlations from $\mathrm{H}_{3}-12\left(\delta_{\mathrm{H}} 1.38\right), \mathrm{H}_{3}-13\left(\delta_{\mathrm{H}} 1.40\right)$ to $\mathrm{C}-7\left(\delta_{\mathrm{C}} 190.4\right), \mathrm{C}-10$ $\left(\delta_{\mathrm{C}} 55.2\right)$, and $\mathrm{C}-11\left(\delta_{\mathrm{C}} 45.1\right)$, and from $\mathrm{H}-8\left(\delta_{\mathrm{H}} 5.93\right)$ to $\mathrm{C}-7$ and $\mathrm{C}-$ $9\left(\delta_{\mathrm{C}}\right.$ 207.1) (Fig. 2) enabled the accomplishment of a fivemembered ring. Besides, the HMBC correlation from $\mathrm{H}_{3}-14$ to C-7 suggested that the two rings are connected via C-6-C-7 (Fig. 2). Therefore, the planar structure of 8 was determined as shown in Fig. 1. Notably, compound 8 represents an unusual sesquiterpene skeleton in nature, holding structural similarity to that of the cuparane-type sesquiterpenes, and we herein designate the skeleton of 8 as $14(7 \rightarrow 6)$-cuparane.

The steric hindrance between the five- and six-membered rings made it possible to establish the absolute configuration of C- 6 by computational methods. The possible conformers of $(6 S)-8$ were generated by the MMFF94s force field conformation search, the geometries with population higher than $1 \%$ were further optimized by density functional theory method at the B3LYP/6-31G(d,p) level on Gaussian 09 program package ${ }^{21}$ to give eight predominant conformers within relative energies

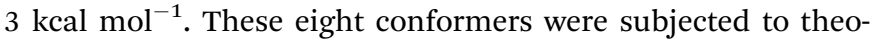
retical calculation of ECD spectra by using the time-dependent DFT method at the B3LYP/6-31G(d,p) in air. As shown in Fig. 6, the calculated ECD spectra for $(6 S)-8$ displayed a similar curve with the experimental CD. Thus, the absolute configuration of 1 was determined as $6 S$. Compound 8 was trivially named as lingzhidienone.

Compound 9, named ganotheaecolin $\mathrm{A}^{22}$ a known isolate reported more recently was encountered in this study. Ganotheaecolin A represented a novel type of steroid with a unique naphtha[1,8-ef]azulene ring system, and it was suggested that 9 exhibited cell differentiation-stimulating activity by a dosedependent manner and reach a maximum effect at $10 \mu \mathrm{M}$. With this fascinating molecule in hand, we evaluated the cytotoxicity of 9 and its acetylated product 9a (5-O-acetyl ganotheaecolin (A) against the five human cancer cell lines HL-60, MCF-7, SW480, A549, and SMMC-7721. Interestingly, compound 9 displayed weak cytotoxicity against five human 
Table 4 Cytotoxicity of 9 toward five human cancer cell lines

\begin{tabular}{|c|c|c|c|c|c|}
\hline \multirow[b]{2}{*}{ Sample } & HL-60 & A-549 & SMMC-7721 & MCF-7 & SW480 \\
\hline & \multicolumn{5}{|c|}{$\mathrm{IC}_{50}(\mu \mathrm{M})$} \\
\hline 9 & 18.8 & 32.3 & 25.1 & 18.1 & 22.3 \\
\hline DDP & 4.7 & 27.6 & 16.0 & 34.8 & 16.1 \\
\hline Taxol & $<0.008$ & $<0.008$ & $<0.008$ & $<0.008$ & $<0.008$ \\
\hline
\end{tabular}

cancer cell lines with $\mathrm{IC}_{50}$ values of $18.0-32.3 \mu \mathrm{M}$ (Table 4), while 9a was devoid of activity $\left(\mathrm{IC}_{50}>40 \mu \mathrm{M}\right)$. The results suggested that the 5-OH of $\mathbf{9}$ was indispensable for its cytotoxicity.

The gymnomitrane and $14(7 \rightarrow 6)$-cuparane scaffolds appear to be biogenetically related. As shown in Scheme 1, the hypothetical biosynthetic pathways of the gymnomitranes (1-6, compound 2 as the illustrative example) and $14(7 \rightarrow 6)$-cuparane (8) are described. First of all, the farnesyl pyrophosphate (FPP) undergoes cascade 1,6- and 7,11-cyclization reactions and a 1,4hydride shift from C-6 to C-10 to give the key intermediate cuparane skeleton. The cuparane yields the gymnomitrane and $14(7 \rightarrow 6)$-cuparane skeleton via two ways. One way is the synchronous methyl and hydride migrations to produce the $14(7 \rightarrow 6)$-cuparane scaffold. The other way is two methyl migrations, i.e. $14(7 \rightarrow 6)$ and $13(11 \rightarrow 7)$, in combination with a 2,11-cyclization reaction to produce the gymnomitrane scaffold. Further enzymatic oxidations and dehydration reactions yield 2 and $\mathbf{8}$.

All the compounds except 6 and 7 were evaluated for their inhibitory activity against NO production. However, none of
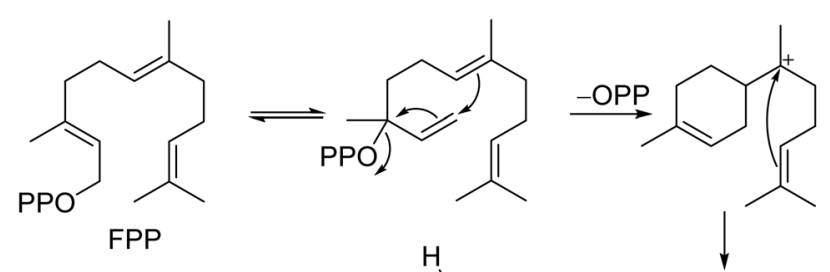

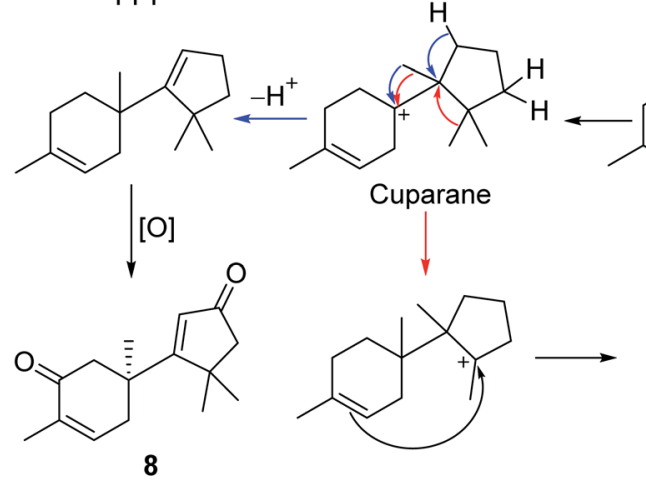
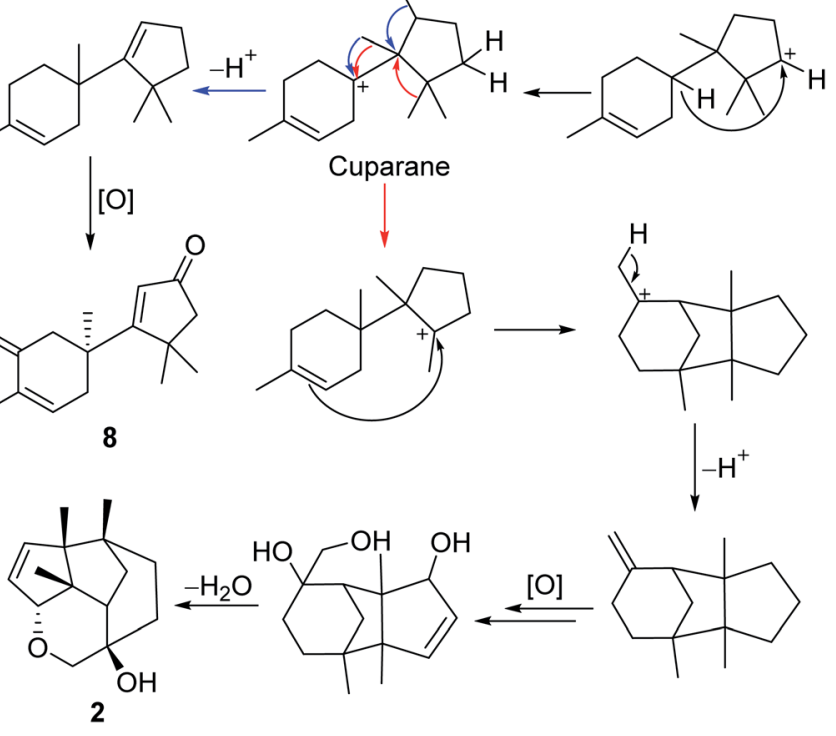

Scheme 1 Proposed biosynthetic pathway of 2 and 8. them showed remarkable inhibitory activities of NO production in murine monocytic RAW 264.7 macrophages at the concentration of $25 \mu \mathrm{M}$.

Compounds 1-5, 8, 9, and 9a were screened for their cytotoxicity against five human cancer cell lines (HL-60, A-549, SMMC-7721, MCF-7, SW480). Compounds 1-5, 8, and 9a were inactive in the cytotoxicity assay $\left(\mathrm{IC}_{50}>40 \mu \mathrm{M}\right)$. Only compound 9 displayed inhibitory activity against the five human cancer cell lines with $\mathrm{IC}_{50}$ values ranging from 18.0 to $32.3 \mu \mathrm{M}$ (Table 4), indicating that $5-\mathrm{OH}$ is essential for its activity.

\section{Conclusions}

In summary, chemical investigation on the edible and medicinal mushroom Ganoderma lingzhi afforded six new gymnomitrane-type sesquiterpenoids (1-6), an unusual sesquiterpenoid (8), and a new polyketide (7) as well as a known steroid (9). The absolute configurations of the isolates were unambiguously determined via single crystal X-ray diffraction analysis, and ECD calculation. The biosynthetic pathway of 1-6 and 8 were also discussed. Among the structures, 2 is a tetracyclic boat-like rigid molecule with a 10,15-epoxy group. Compound 8 possessed an unusual $14(7 \rightarrow 6)$-cuparane scaffold. It is noteworthy that the gymnomitrane-type sesquiterpenoids have rarely been encountered from fungal origin ${ }^{\mathbf{6 1 4 , 2 3}}$ and this work represents the first report of clustered gymnomitranes from Ganoderma, or even from fungi. This work also provides evidence consistent with the genome sequence data of Ganoderma. Although no promising biological assay results are reported in this study, this does not mean that the sesquiterpenoids should be neglected in the development of quality criteria for Ganoderma. More work on identifying the constituents of Ganoderma should be put into practice in the course of preclinical studies prior to clinical use.

\section{Experimental section}

\section{General experimental procedures}

Optical rotations were measured by a JASCO P-1020 digital polarimeter (Horiba, Kyoto, Japan). A UV-2401PC UV-visible recording spectrophotometer (Shimadzu, Kyoto, Japan) was used to record the ultraviolet (UV) spectra. A Chirascan circular dichroism spectrometer (Applied Photophysics Limited, Leatherhead, Surrey, UK) was used to recorded the CD spectra. 1D and 2D NMR spectra were obtained on Bruker Avance III 600 $\mathrm{MHz}$ or Ascend $800 \mathrm{MHz}$ spectrometers (Bruker Corporation, Karlsruhe, Germany). An Agilent 6200 Q-TOF MS system (Agilent Technologies, Santa Clara, CA) was used to acquire the HRESIMS data. A Waters AutoSpec Premier P776 MS system (Waters Corporation, Milford, MA) was used to acquire the HREIMS data. An APEX II DUO spectrophotometer (Bruker AXS $\mathrm{GmbH}$, Karlsruhe, Germany) was applied for performing the single crystal X-ray diffraction experiments. Column chromatography (CC) were run on Sephadex LH-20 (Amersham Biosciences, Uppsala, Sweden) and silica gel (Qingdao Haiyang Chemical Co., Ltd, Qingdao, China). A Büchi Sepacore System (pump manager C-615, pump modules C-605, and fraction 
collector C-660) (Büchi Labortechnik AG, Flawil, Switzerland) was used to perform medium pressure liquid chromatography (MPLC), equipped with a column (400 $\mathrm{mm} \times 7.4 \mathrm{~mm}$ i.d., 40-75 $\mu \mathrm{m}$, flow rate $40 \mathrm{~mL} \mathrm{~min}^{-1}$ ) filled with Chromatorex C-18 (Fuji Silysia Chemical Ltd., Kasugai, Japan) RP-C18 silica gel. An Agilent 1260 liquid chromatography system (Agilent) equipped with an ODS column (Zorbax SB-C18, $150 \mathrm{~mm} \times 9.4 \mathrm{~mm}$ i.d., 5

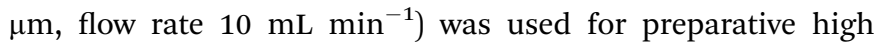
performance liquid chromatography (prep-HPLC).

\section{Fungal material}

The fruiting bodies of $G$. lingzhi were purchased from the herbal trading market of Kunming Luosiwan International Trade City in 2015, and identified by Prof. Yu-Cheng Dai (Beijing Forestry University), an expert in the field of mushroom taxonomy. A voucher specimen (No. HFC 20150518) of G. lingzhi was deposited in the Herbarium of Ethnic Medicinal Plants of South-Central University for Nationalities (SCUEC).

\section{Extraction and isolation}

The air-dried and powdered fruiting bodies of G. lingzhi (10.0 $\mathrm{kg}$ ) was extracted with $95 \%$ ethanol three times (three days each). The extract was evaporated under reduced pressure and partitioned between ethyl acetate and water four times to give a crude extract $(400 \mathrm{~g})$. The crude extract was subject to silica gels with a stepwise gradient of petroleum ether/acetone (from $20: 1 \rightarrow 1: 1, \mathrm{v} / \mathrm{v}$, totally $20 \mathrm{~L}$ ) to afford five fractions (A-E).

Fraction $\mathrm{B}(45 \mathrm{~g})$ was subjected to MPLC with a solvent gradient system of $\mathrm{MeOH} / \mathrm{H}_{2} \mathrm{O}\left(\right.$ from $80: 20 \rightarrow 100: 0, \mathrm{v} / \mathrm{v}, 35 \mathrm{~mL} \mathrm{~min}{ }^{-1}$ ) to obtain twenty-two subfractions (B1 to B22). Subfraction B16 (40 $\mathrm{mg}$ ) was further purified by Sephadex LH-20 (MeOH) and then B16d was separated by prep-HPLC using a gradient elution $\left(\mathrm{MeCN} / \mathrm{H}_{2} \mathrm{O}, 30: 70 \rightarrow 50: 50, \mathrm{v} / \mathrm{v}, 30 \mathrm{~min}, 7 \mathrm{~mL} \mathrm{~min}^{-1}\right)$ to yield compound $2\left(0.7 \mathrm{mg}, t_{\mathrm{R}}=8.5 \mathrm{~min}\right)$. Subfraction B1 (22 mg) was applied to Sephadex $\mathrm{LH}-20(\mathrm{MeOH})$ to afford four minor fractions (B1a to B1d). Compound 8 (2.2 mg, $\mathrm{MeCN} / \mathrm{H}_{2} \mathrm{O}, 10: 90 \rightarrow 35: 65$,

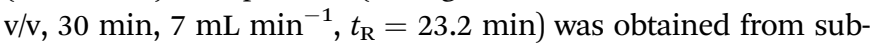
fraction B1c via prep-HPLC. Subfraction B17 (65 mg) was further purified by prep-HPLC using a gradient elution $\left(\mathrm{MeCN} / \mathrm{H}_{2} \mathrm{O}\right.$, $60: 40 \rightarrow 90: 10,30 \mathrm{~min}, 7 \mathrm{~mL} \mathrm{~min}^{-1}$ ) to yield compound 9 $\left(32 \mathrm{mg}, t_{\mathrm{R}}=27.2 \mathrm{~min}\right)$.

Fraction C (27 g) was subjected to MPLC with a gradient solvent system of $\mathrm{MeOH} / \mathrm{H}_{2} \mathrm{O}(80: 20 \rightarrow 100: 0, \mathrm{v} / \mathrm{v}, 35$ $\mathrm{mL} \min ^{-1}$ ) to obtain twenty-two subfractions (C1 to C15). Subfraction C2 (45 mg) was further purified by Sephadex LH-20 $(\mathrm{MeOH})$, then fractions $\mathrm{C} 2 \mathrm{e}, \mathrm{C} 2 \mathrm{f}$ and $\mathrm{C} 2 \mathrm{~g}$ were separated by prep-HPLC to afford compound $1\left(0.9 \mathrm{mg}, \mathrm{MeCN}^{-} \mathrm{H}_{2} \mathrm{O}, 27: 73\right.$ $\rightarrow 42: 58, \mathrm{v} / \mathrm{v}, 20 \mathrm{~min}, 7 \mathrm{~mL} \min ^{-1}, t_{\mathrm{R}}=13.5 \mathrm{~min}$ ), compounds 6/7 mixture $\left(2.6 \mathrm{mg}, \mathrm{MeCN} / \mathrm{H}_{2} \mathrm{O}, 15: 85 \rightarrow 30: 70, \mathrm{v} / \mathrm{v}, 20 \mathrm{~min}\right.$,

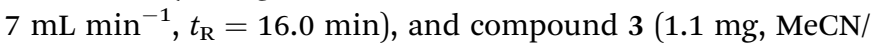
$\left.\mathrm{H}_{2} \mathrm{O}, 20: 80 \rightarrow 40: 60,20 \mathrm{~min}, 7 \mathrm{~mL} \min ^{-1}, t_{\mathrm{R}}=17.2 \mathrm{~min}\right)$, respectively. Subfraction C3 (105 $\mathrm{mg}$ ) was separated by Sephadex LH-20 ( $\mathrm{MeOH}$ ) yielding six minor fractions (C3a to C3f). Next, fraction C3e was applied on Sephadex LH-20 (Acetone) to afford five minor fractions (C3e1 to C3e5), then C3e4 were treated by prep-HPLC to afford compounds 4 (5.0 mg, MeCN/

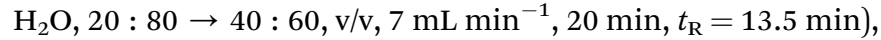
$5\left(10.0 \mathrm{mg}, \mathrm{MeCN} / \mathrm{H}_{2} \mathrm{O}, 20: 80 \rightarrow 40: 60,20 \mathrm{~min}, 7 \mathrm{~mL} \mathrm{~min}{ }^{-1}\right.$, $\left.t_{\mathrm{R}}=4.5 \mathrm{~min}\right)$, respectively.

10 $\alpha$-Hydroxy-gymnomitr-3-en-15-al (1). Colourless needles; m.p. $157.9-160.4{ }^{\circ} \mathrm{C} ;[\alpha]_{\mathrm{D}}^{23}+6.44(c 0.06, \mathrm{MeOH})$; UV (MeOH) $\lambda_{\max }$ $(\log \varepsilon): 241.60$ (3.23); ${ }^{1} \mathrm{H}$ NMR data (Table 1); ${ }^{13} \mathrm{C}$ NMR data (Table 2); HREIMS $m / z 234.1602[\mathrm{M}]^{+}$(calcd for $\mathrm{C}_{15} \mathrm{H}_{22} \mathrm{O}_{2}, 234.1620$ ).

Single crystal $\mathrm{X}$-ray diffraction data for 1 . Crystal data for Cu_1_0m: $\mathrm{C}_{15} \mathrm{H}_{22} \mathrm{O}_{2}, M=234.32, a=7.70800(10) \AA, b=$ $12.5490(2) \AA, c=13.1278(2) \AA, \alpha=90^{\circ}, \beta=90^{\circ}, \gamma=90^{\circ}, V=$ 1269.82(3) $\AA^{3}, T=100(2) \mathrm{K}$, space group $P 2{ }_{1} 2_{1} 2_{1}, Z=4, \mu(\mathrm{CuK} \alpha)$ $=0.621 \mathrm{~mm}^{-1}, 8045$ reflections measured, 2306 independent reflections $\left(R_{\text {int }}=0.0442\right)$. The final $R_{1}$ values were $0.0513(I>$ $2 \sigma(I))$. The final $w R\left(F^{2}\right)$ values were $0.1314(I>2 \sigma(I))$. The final $R_{1}$ values were 0.0513 (all data). The final $w R\left(F^{2}\right)$ values were 0.1315 (all data). The goodness of fit on $F^{2}$ was 1.061. Flack parameter $=0.09(6)$. The crystallographic data were deposited to the Cambridge Crystallographic Data Centre (CCDC) with the No. CCDC 1561836. Copies of the data are available for free from Cambridge Crystallographic Data Centre.

10 $\alpha, 15$-Epoxy-gymnomitr-8-en-3 $\beta$-ol (2). Colourless needles; m.p. $172-175{ }^{\circ} \mathrm{C} ;[\alpha]_{\mathrm{D}}^{22}-47.67$ (c $\left.0.10, \mathrm{MeOH}\right) ;{ }^{1} \mathrm{H}$ NMR data (Table 1); ${ }^{13} \mathrm{C}$ NMR data (Table 2); HREIMS $\mathrm{m} / \mathrm{z} 234.1617[\mathrm{M}]^{+}$ (calcd for $\mathrm{C}_{15} \mathrm{H}_{22} \mathrm{O}_{2}, 234.1620$ ).

15-Hydroxy-gymnomitr-3-en-5-one (3). White amorphous powder; $[\alpha]_{\mathrm{D}}^{23}+174.74(c \quad 0.13, \mathrm{MeOH})$; UV $(\mathrm{MeOH}) \lambda_{\max }(\log \varepsilon)$ : 244.20 (3.87); ${ }^{1} \mathrm{H}$ NMR data (Table 1); ${ }^{13} \mathrm{C}$ NMR data (Table 2); HRESIMS $\mathrm{m} / \mathrm{z}$ 257.1514 $[\mathrm{M}+\mathrm{Na}]^{+}$(calcd for $\mathrm{C}_{15} \mathrm{H}_{22} \mathrm{O}_{2} \mathrm{Na}$, 257.1512)

Gymnomitr-3-ene-13,15-dioic acid (4). Colourless oil, $[\alpha]_{\mathrm{D}}^{23}+151.33(c 0.09, \mathrm{MeOH}) ;{ }^{1} \mathrm{H}$ NMR data (Table 1$) ;{ }^{13} \mathrm{C}$ NMR data (Table 2); HRESIMS $m / z$ 263.1291 [M $-\mathrm{H}]^{-}$(calcd for $\left.\mathrm{C}_{15} \mathrm{H}_{19} \mathrm{O}_{4}, 263.1289\right)$.

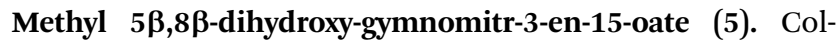
ourless needles; m.p. 137.5-142.2 ${ }^{\circ} \mathrm{C}$; $[\alpha]_{\mathrm{D}}^{24}+86.19(c) 0.14$, $\mathrm{MeOH}) ; \mathrm{UV}(\mathrm{MeOH}) \lambda_{\max }(\log \varepsilon): 221.50$ (3.57); ${ }^{1} \mathrm{H}$ NMR data (Table 1); ${ }^{13} \mathrm{C}$ NMR data (Table 2); HRESIMS $m / z$ 303.1565 [M + $\mathrm{Na}]^{+}$(calcd for $\mathrm{C}_{16} \mathrm{H}_{24} \mathrm{O}_{4} \mathrm{Na}, 303.1567$ ).

Single crystal X-ray diffraction data for 5. Crystal data for

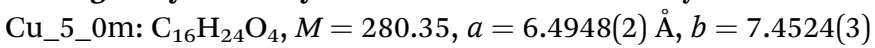
$\AA, c=15.2812(6) \AA, \alpha=90^{\circ}, \beta=101.0040(10)^{\circ}, \gamma=90^{\circ}, V=$ 726.04(5) $\AA^{3}, T=100(2) \mathrm{K}$, space group $P 2_{1}, Z=2, \mu(\mathrm{CuK} \alpha)=$ $0.736 \mathrm{~mm}^{-1}, 7540$ reflections measured, 2510 independent reflections $\left(R_{\text {int }}=0.0263\right)$. The final $R_{1}$ values were $0.0327(I>$ $2 \sigma(I))$. The final $w R\left(F^{2}\right)$ values were $0.0844(I>2 \sigma(I))$. The final $R_{1}$ values were 0.0327 (all data). The final $w R\left(F^{2}\right)$ values were 0.0845 (all data). The goodness of fit on $F^{2}$ was 1.056. Flack parameter $=0.17(3)$. The crystallographic data were submitted to the Cambridge Crystallographic Data Centre (CCDC) with the No. CCDC 1851594. These data can be accessed free from Cambridge Crystallographic Data Centre.

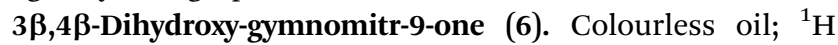
NMR data (Table 1); ${ }^{13} \mathrm{C}$ NMR data (Table 2); HREIMS $\mathrm{m} / \mathrm{z}$ 252.1724 [M] $]^{+}$(calcd for $\mathrm{C}_{15} \mathrm{H}_{22} \mathrm{O}_{3}, 252.1725$ ).

12-O-Methyl-xylaolide A (7). Colourless oil; ${ }^{1} \mathrm{H}$ NMR data (Table 3); ${ }^{13} \mathrm{C}$ NMR data (Table 2); HRESIMS $\mathrm{m} / \mathrm{z}$ 261.1098 [M + $\mathrm{Na}]^{+}$(calcd for $\mathrm{C}_{13} \mathrm{H}_{18} \mathrm{O}_{4} \mathrm{Na}, 261.1097$ ). 
Lingzhidienone (8). Colourless oil; $[\alpha]_{\mathrm{D}}^{23}+22.31$ (c 0.13 , $\mathrm{MeOH}) ; \mathrm{UV}(\mathrm{MeOH}) \lambda_{\max }(\log \varepsilon): 230.80$ (4.23); ${ }^{1} \mathrm{H}$ NMR data (Table 3); ${ }^{13} \mathrm{C}$ NMR data (Table 2); HREIMS $\mathrm{m} / \mathrm{z} 232.1460[\mathrm{M}]^{+}$ (calcd for $\left.\mathrm{C}_{15} \mathrm{H}_{20} \mathrm{O}_{2}, 232.1463\right) ; \mathrm{CD}(\mathrm{MeOH}) \lambda_{\max }(\Delta \varepsilon): 217$ (-12.3), 240 (+20.2), $260(-1.2)$.

Preparation of 5-O-acetyl-ganotheaecolin A (9a). To a solution of ganotheaecolin A $(2.0 \mathrm{mg})$ in anhydrous pyridine $(0.2$ $\mathrm{mL})$ was added $\mathrm{Ac}_{2} \mathrm{O}(0.5 \mathrm{~mL})$, and the mixture was stirred at $25{ }^{\circ} \mathrm{C}$ until the reaction was complete (judged by the disappearance of the starting material by TLC). Excess ethanol was added to the reaction mixture and evaporated under reduced pressure. The crude product was purified by prep-HPLC (MeCN/ $\mathrm{H}_{2} \mathrm{O}, 70: 30 \rightarrow 90: 10,25 \mathrm{~min}, 7 \mathrm{~mL} \mathrm{~min}^{-1}$ ) to yield the corresponding 5-O-acetyl derivative. Application of this procedure afforded the new acetate 5-O-acetyl-ganotheaecolin A (9a).

5-O-Acetyl-ganotheaecolin A (9a): ${ }^{1} \mathrm{H}$ NMR (500 MHz, $\left.\mathrm{CDCl}_{3}\right)$ : $\mathrm{H}-1\left(\delta_{\mathrm{H}} 2.59\right.$, br. d, $J=18.8 \mathrm{~Hz} ; \delta_{\mathrm{H}} 1.75$, overlapped $), \mathrm{H}-2\left(\delta_{\mathrm{H}}\right.$ 6.18, ddd, $J=10.0,5.0,2.5 \mathrm{~Hz})$; H-3 $\left(\delta_{\mathrm{H}} 6.35\right.$, dd, $J=10.0,2.5$ $\mathrm{Hz}) ; \mathrm{H}-11\left(\delta_{\mathrm{H}} 2.31\right.$, ddd, $J=15.0,15.0,3.0 ; \delta_{\mathrm{H}} 1.01$, ddd, $J=15.0$, 4.7, 2.5); H-12 $\left(\delta_{\mathrm{H}} 1.96\right.$, ddd, $J=15.0,5.0,3.0 \mathrm{~Hz} ; \delta_{\mathrm{H}} 1.34$, br. d, $J$ $=15.0 \mathrm{~Hz}) ; \mathrm{H}-14\left(\delta_{\mathrm{H}} 3.41, \mathrm{dd}, J=12.5,7.2 \mathrm{~Hz}\right) ; \mathrm{H}-15\left(\delta_{\mathrm{H}} 1.79\right.$, overlapped; $\delta_{\mathrm{H}} 1.61$, overlapped $) ; \mathrm{H}-16\left(\delta_{\mathrm{H}} 1.74\right.$, overlapped; $\delta_{\mathrm{H}}$ 1.41, overlapped); $\mathrm{H}-17\left(\delta_{\mathrm{H}} 1.61, \mathrm{~m}\right) ; \mathrm{H}-18\left(\delta_{\mathrm{H}} 0.79, \mathrm{~s}, 3 \mathrm{H}\right) ; \mathrm{H}-19$ $\left(\delta_{\mathrm{H}} 0.72, \mathrm{~s}, 3 \mathrm{H}\right) ; \mathrm{H}-20\left(\delta_{\mathrm{H}} 2.14, \mathrm{~m}\right) ; \mathrm{H}-21\left(\delta_{\mathrm{H}} 1.04, \mathrm{~d}, J=6.7 \mathrm{~Hz}\right)$; $\mathrm{H}-22\left(\delta_{\mathrm{H}} 5.20, \mathrm{dd}, J=15.3,7.5 \mathrm{~Hz}\right) ; \mathrm{H}-23\left(\delta_{\mathrm{H}} 5.24, \mathrm{dd}, J=15.3\right.$, $7.0 \mathrm{~Hz}) ; \mathrm{H}-24\left(\delta_{\mathrm{H}} 1.86, \mathrm{~m}\right) ; \mathrm{H}-25\left(\delta_{\mathrm{H}} 1.47, \mathrm{~m}\right) ; \mathrm{H}-26\left(\delta_{\mathrm{H}} 0.82, \mathrm{~d}, J=\right.$ $6.8 \mathrm{~Hz}) ; \mathrm{H}-27\left(\delta_{\mathrm{H}} 0.84, \mathrm{~d}, J=6.8 \mathrm{~Hz}\right) ; \mathrm{H}-28\left(\delta_{\mathrm{H}} 0.92, \mathrm{~d}, J=6.8 \mathrm{~Hz}\right)$; ${ }^{13} \mathrm{C} \mathrm{NMR}\left(125 \mathrm{MHz}, \mathrm{CDCl}_{3}\right)$ : C-1 $\left(\delta_{\mathrm{C}} 40.0\right)$; C-2 $\left(\delta_{\mathrm{C}} 137.3\right)$; C-3 $\left(\delta_{\mathrm{C}}\right.$ $127.0) ; \mathrm{C}-4\left(\delta_{\mathrm{C}} 168.9\right) ; \mathrm{C}-5\left(\delta_{\mathrm{C}} 131.9\right) ; \mathrm{C}-6\left(\delta_{\mathrm{C}} 184.5\right) ; \mathrm{C}-7\left(\delta_{\mathrm{C}}\right.$ $127.0) ; \mathrm{C}-8\left(\delta_{\mathrm{C}} 162.3\right) ; \mathrm{C}-9\left(\delta_{\mathrm{C}} 74.2\right) ; \mathrm{C}-10\left(\delta_{\mathrm{C}} 41.4\right) ; \mathrm{C}-11\left(\delta_{\mathrm{C}} 33.1\right)$; C-12 $\left(\delta_{\mathrm{C}} 33.8\right) ; \mathrm{C}-13\left(\delta_{\mathrm{C}} 43.5\right) ; \mathrm{C}-14\left(\delta_{\mathrm{C}} 47.8\right) ; \mathrm{C}-15\left(\delta_{\mathrm{C}} 27.0\right) ; \mathrm{C}-16$ $\left(\delta_{\mathrm{C}} 27.2\right) ; \mathrm{C}-17\left(\delta_{\mathrm{C}} 56.7\right) ; \mathrm{C}-18\left(\delta_{\mathrm{C}} 18.7\right) ; \mathrm{C}-19\left(\delta_{\mathrm{C}} 19.8\right) ; \mathrm{C}-20\left(\delta_{\mathrm{C}}\right.$ 40.5); C-21 ( $\left.\delta_{\mathrm{C}} 22.0\right) ; \mathrm{C}-22\left(\delta_{\mathrm{C}} 134.9\right) ; \mathrm{C}-23\left(\delta_{\mathrm{C}} 133.0\right) ; \mathrm{C}-24\left(\delta_{\mathrm{C}}\right.$ 43.5); C-25 ( $\left.\delta_{\mathrm{C}} 33.2\right)$; C-26 $\left(\delta_{\mathrm{C}} 19.8\right)$; C-27 $\left(\delta_{\mathrm{C}} 20.2\right)$; C-28 $\left(\delta_{\mathrm{C}} 17.8\right)$.

\section{Bioassays}

\section{Nitric oxide production in RAW 264.7 macrophages}

The RPMI 1640 medium (Hyclone, Logan, UT) containing 10\% FBS was used to culture the murine monocytic RAW 264.7 macrophages. The compounds were dissolved in DMSO and further diluted in medium to produce different concentrations. The culture medium and cell mixture were dispensed into 96well plates $\left(2 \times 10^{5}\right.$ cells per well $)$ and maintained at $37{ }^{\circ} \mathrm{C}$ under $5 \% \mathrm{CO}_{2}$ in a humidified atmosphere. After preincubation for $24 \mathrm{~h}$, serial dilutions of the test compounds were added into the cells, up to the maximum concentration $25 \mu \mathrm{M}$, then LPS was added to a concentration $1 \mu \mathrm{g} \mathrm{mL}^{-1}$ and incubation continued for $18 \mathrm{~h}$. After addition of $100 \mu \mathrm{L}$ of Griess reagent (reagent A and reagent B, Sigma, St. Louis, Mo) to $100 \mu \mathrm{L}$ of each supernatant from the LPS-treated or LPS- and compoundtreated cells in triplicate and incubation for $5 \mathrm{~min}$, NO production of each cell was assessed by sample absorbance at $570 \mathrm{~nm}$ by a 2104 Envision Multilabel Plate Reader. L- $N^{\mathrm{G}}$ Monomethyl arginine (L-NMMA) was used as a positive control.

Cytotoxicity against five human cancer cell lines. The following five human cancer cell lines were used: the HL-60
(ATCC CCL-240) human myeloid leukemia; SMMC-7721 human hepatocellular carcinoma; A-549 (ATCC CCL-185) lung cancer; MCF-7 (ATCC HTB-22) breast cancer; SW-480 (ATCC CCL-228) human colon cancer. The cell line SMMC-7721 was bought from China Infrastructure of Cell Line Resources (Beijing, China), and others were bought from American Type Culture Collection (ATCC, Manassas, VA). All cells were cultured in RPMI-1640 medium containing 10\% fetal bovine serum (FBS) (Hyclone) and maintained at $37{ }^{\circ} \mathrm{C}$ under $5 \% \mathrm{CO}_{2}$ in a humidified atmosphere. Colorimetric measurements of the amount of insoluble formazan which was produced in living cells based on the reduction of 3-(4,5-dimethylthiazol-2-yl)-2,5diphenyltetrazolium bromide (MTT) (Sigma, St. Louis, MO) was used to assess cell viability. In brief, each well of a 96-well cell culture plate was seeded with $100 \mu \mathrm{L}$ of adherent cells and kept for $12 \mathrm{~h}$ for adherence, and then added with test compounds, however, suspended cells were seeded before added with test compounds with both the same density of 1 $\times 10^{5}$ cells per $\mathrm{mL}$ every $100 \mu \mathrm{L}$ of culture medium. After different concentrations of test compounds addition, each cancer cell line was incubated for $48 \mathrm{~h}$ in triplicate. Cisplatin was used as positive control. After the incubation, each well was treated with MTT $(100 \mu \mathrm{g})$ and incubation continued for $4 \mathrm{~h}$ at $37{ }^{\circ} \mathrm{C}$. After removal of the $100 \mu \mathrm{L}$ culture medium, the cells were lysed with $20 \%$ SDS-50\% DMF $(100 \mu \mathrm{L})$. The remaining lysates were subjected to measure of optical density at $595 \mathrm{~nm}$ with a 96-well microtiter plate reader. The $\mathrm{IC}_{50}$ value for each compound was calculated by a published method. ${ }^{24}$

\section{Quantum chemistry calculation details}

A conformation search based on molecular mechanics with MMFF94s force fields were performed for (6S)-8 gave 10 stable conformers with distributions higher than $1 \%{ }^{25,26}$ All these conformers were further optimized by the density functional theory method at the B3LYP/6-31G(d,p) level in Gaussian 09 program package,$^{21}$ leading to six $((6 S)-8 \mathbf{a}-(6 S)-8 f)$ conformers within $3 \mathrm{kcal} \mathrm{mol}^{-1}$ energy threshold from global minimum, respectively. The predominant conformers were subjected to theoretical calculation of ECD using time-dependent density functional theory (TDDFT) at B3LYP/6-31G(d,p) level with IEFPCM model in air based on B3LYP/6-31G(d,p) optimized conformers. The calculated ECD curves for $(6 S)$-8 were weighted using SpecDis 1.71 with $\sigma=0.2 \mathrm{eV}$, and UV shift $11 \mathrm{~nm}$, respectively. ${ }^{27}$ The ECD curve of the enantiomer (6R)-8 was generated by SpecDis by the function "enantiomeric ECD".

\section{Conflicts of interest}

There are no conflicts to declare.

\section{Acknowledgements}

We thank the Analytical and Measuring Center, School of Pharmaceutical Sciences, South-Central University for Nationalities for MS and NMR spectra tests. This work was financially supported by National Natural Science Foundation of China 
(81903512, 81773590), and the Start-up Research Funds of South-Central University for Nationalities (YZZ17011).

\section{Notes and references}

1 M. F. Ahmad, Biomed. Pharmacother., 2018, 107, 507.

2 K. S. Bishop, C. H. J. Kao, Y. Y. Xu, M. P. Glucina, R. R. M. Paterson and L. R. Ferguson, Phytochemistry, 2015, 114, 56.

3 Y. C. Dai, L. W. Zhou, T. Hattori, Y. Cao, J. A. Stalpers, L. Ryvarden, P. Buchanan, F. Oberwinkler, N. Hallenberg, P. G. Liu and S. H. Wu, Mycol. Prog., 2017, 16, 1051.

4 S. Baby and A. J. Johnson, Phytochemistry, 2015, 114, 66. 5 D. Cör, Ž. Knez and M. K. Hrnčič, Molecules, 2018, 23, 649. 6 H. P. Chen, Z. Z. Zhao, Y. Zhang, X. Bai, L. Zhang and J. K. Liu, RSC Adv., 2016, 6, 64469.

7 J. Wang, B. Cao, H. P. Zhao and J. Feng, Aging Dis., 2017, 8, 691.

8 X. Peng and M. Qiu, Nat. Prod. Bioprospect., 2018, 8, 137.

9 K. D. Hsu and K. C. Cheng, Appl. Microbiol. Biotechnol., 2018, $102,9037$.

10 P. J. Zeng, Z. H. Guo, Z. Zeng, C. Hao, Y. R. Zhang, M. Zhang, Y. Liu, H. Li, J. Li and L. J. Zhang, J. Cell. Mol. Med., 2018, 22, 3278.

11 H. P. Chen and J. K. Liu, Prog. Chem. Org. Nat. Prod., 2017, 106, 1.

12 S. L. Chen, J. Xu, C. Liu, Y. J. Zhu, D. R. Nelson, S. G. Zhou, C. F. Li, L. Z. Wang, X. Guo, Y. Z. Sun, H. M. Luo, Y. Li, J. Y. Song, B. Henrissat, A. Levasseur, J. Qian, J. Q. Li, X. Luo, L. C. Shi, L. He, L. Xiang, X. L. Xu, Y. Y. Niu, Q. S. Li, M. V. Han, H. X. Yan, J. Zhang, H. M. Chen, A. P. Lv, Z. Wang, M. Z. Liu, D. C. Schwartz and C. Sun, Nat. Commun., 2012, 3, 913.

13 J. Q. Liu, C. F. Wang, Y. Li, H. R. Luo and M. H. Qiu, Planta Med., 2012, 78, 368.

14 P. T. Binh, D. Descoutures, N. H. Dang, N. P. D. Nguyen and N. T. Dat, Nat. Prod. Commun., 2015, 10, 1911.

15 Y. Cao, S. H. Wu and Y. C. Dai, Fungal Divers., 2012, 56, 49. 16 C. Richter, K. Wittstein, P. M. Kirk and M. Stadler, Fungal Divers., 2015, 71, 1.
17 Z. L. Yang and B. Feng, Mycology, 2013, 4, 1.

18 Y. M. Yan, X. L. Wang, Q. Luo, L. P. Jiang, C. P. Yang, B. Hou, Z. Z. Zuo, Y. B. Chen and Y. Z. Cheng, Phytochemistry, 2015, 114, 155.

19 Y. T. Huang, H. S. Chang, G. J. Wang, C. H. Lin and I. S. Chen, Int. J. Mol. Sci., 2012, 13, 16430.

20 B. Yang, J. Dong, X. Lin, H. Tao, X. Zhou and Y. Liu, Nat. Prod. Res., 2014, 28, 967.

21 M. J. Frisch, G. W. Trucks, H. B. Schlegel, G. E. Scuseria, M. A. Robb, J. R. Cheeseman, G. Scalmani, V. Barone, G. A. Petersson, H. Nakatsuji, X. Li, M. Caricato, A. Marenich, J. Bloino, B. G. Janesko, R. Gomperts, B. Mennucci, H. P. Hratchian, J. V. Ortiz, A. F. Izmaylov, J. L. Sonnenberg, D. Williams-Young, F. Ding, F. Lipparini, F. Egidi, J. Goings, B. Peng, A. Petrone, T. Henderson, D. Ranasinghe, V. G. Zakrzewski, J. Gao, N. Rega, G. Zheng, W. Liang, M. Hada, M. Ehara, K. Toyota, R. Fukuda, J. Hasegawa, M. Ishida, T. Nakajima, Y. Honda, O. Kitao, H. Nakai, T. Vreven, K. Throssell, J. A. Montgomery Jr., J. E. Peralta, F. Ogliaro, M. Bearpark, J. J. Heyd, E. Brothers, K. N. Kudin, V. N. Staroverov, T. Keith, R. Kobayashi, J. Normand, K. Raghavachari, A. Rendell, J. C. Burant, S. S. Iyengar, J. Tomasi, M. Cossi, J. M. Millam, M. Klene, C. Adamo, R. Cammi, J. W. Ochterski, R. L. Martin, K. Morokuma, O. Farkas, J. B. Foresman and D. J. Fox, Gaussian 09, Revision D.01, Gaussian, Inc., Wallingford CT, 2013.

22 Q. Luo, Z. L. Yang, Y. M. Yan and Y. X. Cheng, Org. Lett., 2017, 19, 718.

23 Z. M. Chen, H. P. Chen, F. Wang, Z. H. Li, T. Feng and J. K. Liu, Fitoterapia, 2015, 102, 61.

24 L. J. Reed and H. Muench, Am. J. Epidemiol., 1938, 27, 493. 25 H. Goto and E. Osawa, J. Am. Chem. Soc., 1989, 111, 8950.

26 H. Goto and E. Osawa, J. Chem. Soc., Perkin Trans. 2, 1993, 187.

27 T. Bruhn, A. Schaumlöffel, Y. Hemberger and G. Bringmann, Chirality, 2013, 25, 243. 